\title{
Field Test Research of Earth Pressure on the Gabion Retaining Wall
}

\author{
Jinkui Li $\mathrm{i}^{\mathrm{a}}$, Wenjing Liang ${ }^{*}, \mathrm{~b}$, Xianke Wei ${ }^{\mathrm{c}}$ \\ Department of Civil and Architecture Engineering, Dalian \\ University, Dalian 116622, China \\ ajinkee@126.com, b18617561784@163.com, \\ cliangwenjing999@163.com
}

\begin{abstract}
Combined with the north project of Dalian international oil reserve, based on the monitoring of box gabion stone retaining wall, the earth pressure of box type reinforced gabion retaining wallwas studied. It can be further development of this technology, provides an example for the comprehensive application of the technology. It can be the reference and guidance for similar engineering, and has important theoretical significance and engineering application value.
\end{abstract}

\section{Keywords-Gabion retaining wall, Field test, Earth pressure}

\section{INTRODUCTION}

The wide disseminationand the development of the reinforced earth technique of the times is the 1970s. In academic circles France, USA and Japan is particularly active, they have drawn some conclusions corresponding calculation in the reinforcement of the pull of the hand. For example, K.L.Lee, D.P. Mckittrickand other scholars of the University of Californiahave made outstanding contributions in the fracture surface morphology, and they hold international seminars in Sydney, Paris and other places, to enhance mutual exchanges, to discuss the related theory of reinforced soil and experimental results.

Our technology research and application of reinforced earth began in the mid -1970s.In 1978, China's first test of reinforced earth retaining wall was built in Yunnan Tin Par Coal Depot, and in 1980 Highway reinforced first earth retaining wall was built in the road of Shanxi Jincheng Lingchuan. Reinforced earth retaining wall has been used in road, rail, water, construction, and mining and other sectors, particularly road sector most widely used.

Thus, reinforced earth retaining wall as a retaining structures, it has nearly 50 years of history from the formal and practical until now. During the period, there are many scientists put a lot of effort to do all kinds of research, simulation test, so as to put forward relevant theory, they greatly enriched the content of the reinforced earth retaining wall.

According to different methods, the test of the reinforced soil structure can be divided into three main aspects: triaxial test, indoor model test and in-situ test. Among them, the in-situ test, also known as on-site full-scale test , although it is not the economy, but to reflect the actual situation reinforced the project, contribute to the character and mechanism of reinforced soil retaining walls reinforced a deeper , closer actual understanding.

Collin[1] observed the seismic response of the reinforced soil structure in the field; Tatsuoka[2] observed long-term performance of railway embankment reinforced soil retaining wall; Xiang Wang et al.[3] conducted a field test on the embankment in situ Reinforced Soil Retaining wall plate railway level earth pressure, soil behind the wall reinforced vertical earth pressure and deformation of the material; Guangqing Yang[4] conducted a field test, including the reinforced earth wall base stress, the dorsal wall of the earth pressure, tension and wall reinforcement horizontal deformation and so on. Field tests and observation directly reflect the mechanical properties of reinforced structures.Therefore, experimental research is valuable information for each site.

As the main research content of reinforced soil retaining wall,the development of reinforced earth structureis rapid, but it is still not perfect and need further study.

\section{ENGINEERING SITUATION}

Dalian Petro-China international reserve north project is located in Dagushan Peninsula of Dalian City, which is in a period of construction of oil depot, the two phase of the project on the west side of the two hill on the ground. The total capacity of new reservoir engineering design is 420 $\times 104 \mathrm{~m}^{3}$. There are 42 bases of oil tank, and oil depot design grade is one class. The length of retaining wall is $1800 \mathrm{~m}$, including east of it is Planning Road, retaining wall's length of Planning Road is $750 \mathrm{~m}$, south of it is Hainian Road, total length is $1050 \mathrm{~m}$. Retaining wall is divided into five levels, but due to the terrain caused by high or low, there is part of the retaining wall is one to four. Overview diagram and profile of the retaining wall wereshown in Fig.1\& Fig. 2.

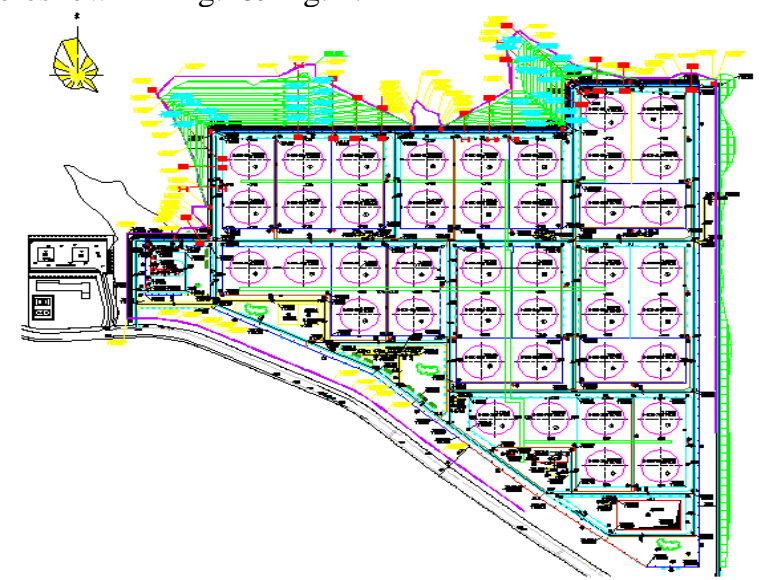

Figure 1. The Engineering Situation of Dalian Petro-China International Reserve North Project 


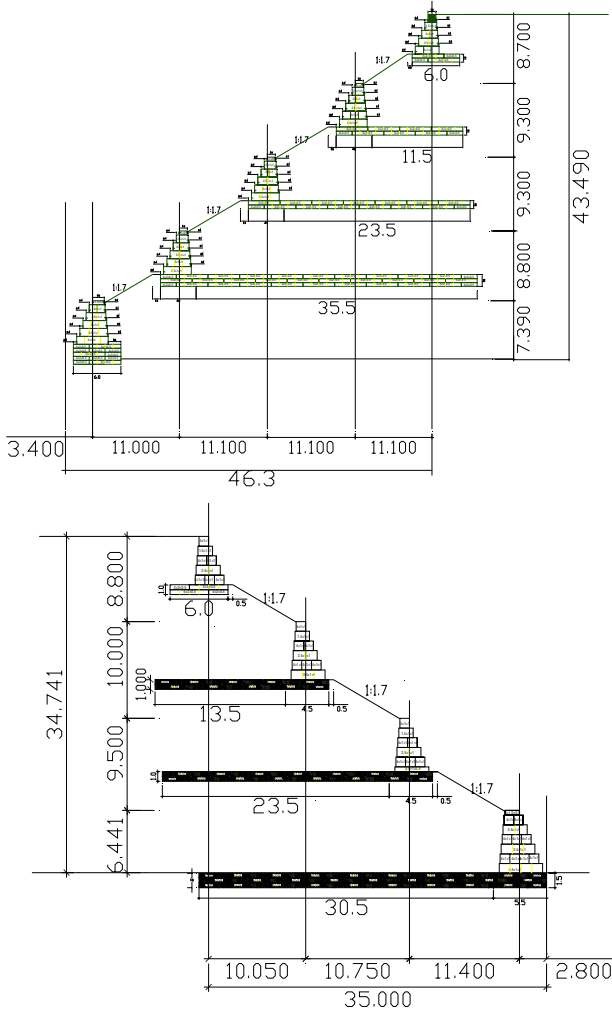

Figure 2. The Profile of Dalian Petro-China International Reserve North Project

\section{FIELD TEST}

The earth pressure is lateral pressure, which generated by backfill on retaining wall to wall back due to weight or external loads. In Dalian Petro-China international reserve north project, the required test pressure is soil backfill soil, mainly through the pre buried steel string type soil pressure box to measure.

In order to effectively monitor the soil pressure, the project has 12 measuring points be arranged. It has two sections been arranged in the sea catfish roadside, respectively in the five level cages backfill most lower position X0+634.0 section, 1, 2, 3, 4, 5 level of net cage backfill the bottom of each arrangement of one pressure cell $(\mathrm{X} 0+634.0-1, \quad \mathrm{X} 0+634.0-2, \quad \mathrm{X} 0+634.0-3, \quad \mathrm{X} 0+634.0-4$, $\mathrm{X} 0+634.0-5)$.

In the four level cages backfill the lowest position, the X0+364.0 section's 2, 3 level of net cage backfill bottom position of each layout 1 pressure box, labeled X0+314.0-1 and $\mathrm{X} 0+314.0-2$

The arrangement of one section of Planning Road, is located in the grade four's lowest position of D0+191 section of backfilling, one pressure box arranged in its coordinates to $1,3,4$ and backfill under the cages, labeled D0+191-1, D0+191-3, D0+191-4.

The one section is arranged at the connecting section, located on the five level network of X0+1050 section of backfilling position, Pressure boxes were arranged in a cage at the bottom of the 1,2-level backfill , labeled X0 + 1050-1 and X0 + 1050-2.

\section{ANALysis OF Test REsults}

\section{A Arius Road}

There are 2 level pressure boxes in Dalian international oil reserve base in the north Arius road retaining wall engineering, labeled $\mathrm{HN} 12 \mathrm{H}$ and $\mathrm{HN} 23 \mathrm{H}$, monitoring horizontal soil pressure of retaining wall 's 5 and 4 level.

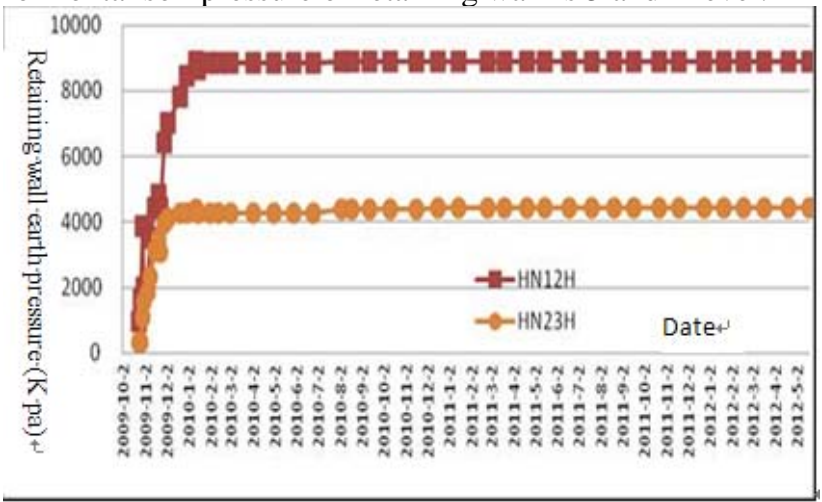

Figure 3. Arius road earth pressure distribution

The horizontal earth pressure variation law of 5 level retaining wall pressure box as shown in Fig.3. Its earth pressure value becomes $983.28 \mathrm{kPa}$ after embedded fill compacted earth behind the initial. With the construction of retaining wall , next day the earth pressure is $3855.72 \mathrm{kPa}$ and it has increased 3.92 times. Then two days later earth pressure values were $2018.49 \mathrm{kPa}$ and $2018.68 \mathrm{kPa}$. It were up to 2.052 times and 2.053 times relative to the initial values. But the earth pressure value decreased 0.52 times relative to the previous day. It was showing that the horizontal earth pressure value affected by retaining wall construction greatly. At the end of this layer retaining wall construction, earth pressure is $4428.48 \mathrm{kPa}$ and earth pressure increased 4.5 times compared with the initial value. At the end of retaining wall construction on the January 12, 2010 earth pressure is $8888.95 \mathrm{kPa}$ and earth pressure increased 9.04 times compared with the initial value, finally close to stabilized.

\section{B Convergence Section}

There are 2 level pressure boxes in Dalian international oil reserve base in the north linking segment. Their number is $\mathrm{HN} 1 \mathrm{H}$ and HN1V. The variation law was shown as Fig. 4 . 


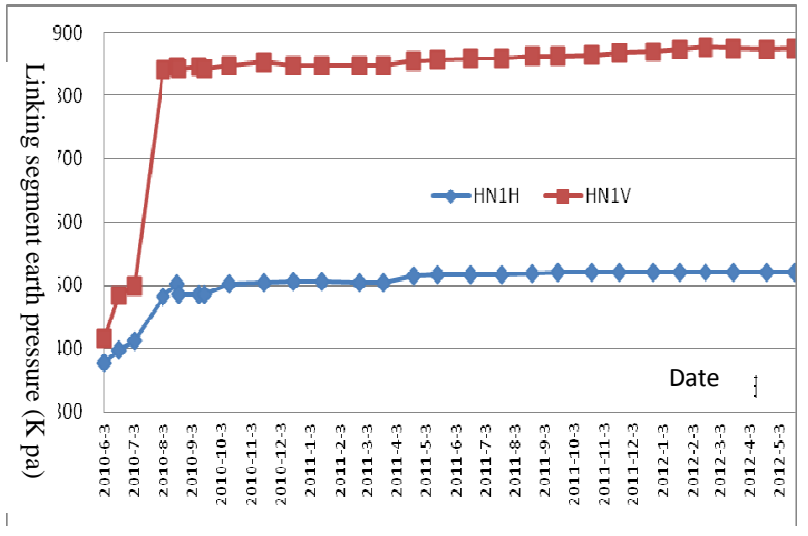

Figure 4. Linking segment earth pressure distribution

The initial value of linking segment earth pressure box $\mathrm{HN} 1 \mathrm{H}$ is $378.04 \mathrm{kPa}$. At the end of retaining wall construction, the earth pressure value on $\mathrm{HN} 1 \mathrm{H}$ is 481.53 $\mathrm{KPa}$ and increased 1.27 times compared with the initial value. By May 29, 2012, the cumulative soil pressure is 521.27 , the growth of $37.4 \mathrm{kPa}$. Growth rates were $3.9 \%$ and $7.6 \%$, almost without any change, a steady state is reached.

\section{CONCLUSION}

When compared with common sections and cohesive segment of the embankment retaining wall data in completion, it is not difficult to find that each value of earth pressure showed a similar variation regularity of initial growth steady rapid late. However, the common section of earth pressure over the initial installation increased 9.04 fold after close to steady state in the wall of the end of construction, yet the convergence section of earth pressure increase only 1.27 times.

The pressure box data basically stable is stable in the layer retaining wall construction. With the passage of time, the change of earth pressure is not big.

\section{ACKNOWLEDGEMENTS}

The paper was supported by the National Natural Science Funds of China 50704007.

\section{CORRESPONDING AUTHOR}

Wenjing Liang, Department of Civil and Architecture Engineering, Dalian University, Dalian, China.

Email:liangwenjing999@163.com

Tel: 8613654916028

\section{REFERENCES}

[1] Collin J G, Chouery-curtis V E, Berg R R. Field observations of reinforced soil structures under seismic loading. In: proceeding of the international symposium on earth. Reinforcement practice, Fukuoka, JaPan(1992), in press.

[2] Tatsuoka F, Tateyama M, Koseki J. Performance of soil retaining for railway embankments. Soil and foundation,(Special issue on geotechnical aspects of the January 17,1995, Hyogoken-Nanbu Earthquake).1996,311-324

[3] Wang Xiang, Zhou Shunhua and GuXiangsheng, et al. an Experimental Study on the ReinforcedRetaningWall for Embankment: China Civil Engineering Journal. Forum Vol.38 (2005), p.119-124

[4] YANG Guang-qing, LU Peng and PANG Wei, et al. Research on Geogrid Reinforced Soil Retaining Wall with Wrapped Face by In-Situ Tests: Rock and Soil Mechanics. Forum Vol.29 (2008), p.517-522 